\title{
CLINICAL ASPECTS OF SURGICAL TREATMENT OF THORACOLUMBAR DISC DISEASE IN DOGS. A RETROSPECTIVE STUDY OF 300 CASES.
}

\author{
A. NEČAS
}

Clinic of Surgery and Orthopedics, University of Veterinary and Pharmaceutical Sciences, Brno, Czech Republic

Received March 4, 1999

Accepted March 31, 1999

Abstract

Nečas A.: Clinical Aspects of Surgical Treatment of Thoracolumbar Disc Disease in Dogs. A Retrospective Study of 300 Cases. Acta Vet. Brno 1999, 68: 121-130.

The clinical records of 300 dogs with thoracolumbar disc disease treated by decompressive surgery at the Clinic of Surgery and Orthopedics at University of Veterinary and Pharmaceutical Sciences in Brno during a four year period (April 1994 through March 1998) were reviewed. The breed, age and sex predisposition, the frequency of disc extrusion at each intervertebral disc space in thoracolumbar region of spine, and the location of extruded disc material relative to the spinal cord were recorded. The number of patients with multiple disc herniations was also recorded. Dogs were grouped by clinical signs of disease into five groups (I, II, III, IVA, IVB and IVC grades). Recovery rates depending on the preoperative neurological grade of spinal injury and duration of clinical signs were compared. Patients were observed at least 9 months after surgery. All dogs were treated by hemilaminectomy without prophylactic fenestration of other disc spaces. The results of treatment in ten dogs with grade II involvement were excellent in $80 \%$ of these dogs, very good in $10 \%$, and fair in $10 \%$. The results of treatment in 68 dogs with grade III involvement were excellent in $80.88 \%$ of these patients, very good in $8.82 \%$, and fair in $10.29 \%$. The results of treatment in 111 dogs with grade IV A involvement in which decompression was performed within 48 hours of the onset of clinical signs were excellent in $71.17 \%$ of these patients, very good in $12.61 \%$, fair in $14.42 \%$, and poor in $1.80 \%$. The results of treatment in 56 dogs with grade IV A involvement in which decompression was performed later than 48 hours after onset of paraplegia were excellent in $46.43 \%$, very good in $25.00 \%$, fair in $17.87 \%$, and poor in $10.70 \%$. Hemilaminectomy was performed in thirty-one dogs with severe neurological dysfunction (group IV B) within 48 hours after onset of paraplegia. Outcome of the surgery was excellent in $22.58 \%$ of these patients, very good in $6.45 \%$, fair in $48.39 \%$, and poor in $22.58 \%$. The results of treatment in 5 dogs with grade IV C involvement were excellent in $40 \%$ of these patients, and fair in $60 \%$.

Nineteen dogs died in the perioperative or early postoperative period and thus were lost to follow-up. Recurrence of neurological deficits in the remaining group of 281 clinical patients was assessed. The recurrence rate observed from 9 to 51 months after surgery, was $14.59 \%$ (41 cases). Fourteen dogs had a recurrence of paraparesis (grade II and III) and twenty-seven dogs had paraplegia (grade IV) 1 to 30 months (mean $10.27 \pm 7.25$ months) after surgery. In all 41 cases cause of the recurrence was extrusion of other disc.

Intervertebral disc disease, dog, spinal cord, hemilaminectomy, recurrence

Intervertebral disc herniations in thoracolumbar region of the spine are the most common cause of paralysis in dogs. Thoracolumbar disc lesions represent from 84 to $86 \%$ of the clinical cases of intervertebral disc disease seen in dogs (Gage 1975; Hoerlein 1978). Although intervertebral disc disease (IVDD) has been recognized in at least 84 breeds of dogs, chondrodystrophoid breeds of dogs are the most commonly affected and the Dachshund predominates (Gage 1975; Hoerlein 1978). Different pathogenetic factors have been proposed to play a role in the initiation of disc degeneration (B raund 1981). Morphological changes which occur within the disc, known as Hansen type I lesions, are recognised in the chondrodystrophoid dogs due to chondroid metaplasia occurring within the first few years of life (Bray and Burbidge 1998). During this type of metaplasia nucleus pulposus is replaced by hyaline cartilage and the process is followed by

Address for correspondence:

MVDr. Alois Nečas, Ph.D.

Clinic of Surgery and Orthopedics

University of Veterinary and Pharmaceutical Sciences

Palackého 1-3,612 42 Brno, Czech Republic

Phone: +42060274 2484

http://www.vfu.cz/acta-vet/actavet.htm 
mineralisation of the disc. Type I prolapses consist of a total rupture of the annulus fibrosus and extrusion of the nucleus pulposus. They are explosive and often associated with significant hemorhage from the vertebral venous plexus. The associated local inflammatory reaction may result in creation of fibrinous adhesions between the herniated disc material and dura mater. Rapidity and severity of degenerative changes of discs in chondrodystrophoid breeds may be attributed to ultrastructural differences between the discs of chondrodystrophoid dogs and those of the nonchondrodystrophoid dogs. Analysis of the ultrastructure of both the nucleus pulposus and annulus fibrosus in both the above mentioned breeds of dogs, reveals remarkable differences in the quantity and quality of collagen, proteoglycans, and glycosaminoglycans (Braund et al. 1975; Ghosh et al. 1977a; Ghosh et al. 1977b). The occurrence of Hansen type I lesions reflects the poor differentiation of intervertebral disc in chondrodystrophoid animals (Bray and Burbidge 1998).

Thoracolumbar disc herniations occur most commonly between T11-T12 and L1-L2 vertebral interspaces (Hoerlein 1978). The linear distribution of the protruded material within the vertebral canal has been classified (Funkquist 1962a). The lesion may remain localised and affect only a few spinal cord segments or it can progress both cranially and caudally in an autodestructive manner (Griffiths 1972). The age incidence for clinical manifestation of the disease in chondrodystrophoid breeds is highest at 3 to 6 years ( To o mbs and Bauer 1993). Males and females are approximately at equal risk (Hoerlein 1953). Only Priester (1976) reported on estrogen's protective effects against disc degeneration.

There is controversy about the treatment of thoracolumbar disc disease with regard to the necessity for decompressive surgery, the type of decompressive surgery, the necessity to retrieve extruded disc material, and the therapeutic value of disc fenestration.

The goal of our study was to assess recurrence of neurological deficits in this sample of clinical patients treated for thoracolumbar disc extrusion with a decompressive procedure alone (hemilaminectomy). Different clinical aspects of thoracolumbar disc prolapse on an extensive sample of 300 patients, including breed, age and sex predisposition, the frequency of disc extrusion at each intervertebral space, and lateralisation of the extrusion were analysed. The number of single versus multiple disc herniations in a given patient was also recorded. Recovery rates depending on the pre-operative neurological grade of spinal injury and duration of clinical signs were compared.

\section{Materials and Methods}

The clinical records of 300 dogs with thoracolumbar disc disease treated by decompressive surgery at the Clinic of Surgery and Orthopedics at University of Veterinary and Pharmaceutical Sciences in Brno during a four year period (April 1994 through March 1998) were reviewed. Nineteen of these patients died during the perioperative or early postoperative period and were lost to follow-up. Data in which long-term follow up was not necessary, were analysed in all 300 animals. The age, breed, sex and the occurrence of any previous thoracolumbar disc disease were recorded. Each dog received standard diagnostic evaluation, including neurological examination. All dogs were classified into groups according to severity of signs (Toombs and B auer 1993). The duration of clinical signs was defined as the interval between the appearance of initial neurological deficit, which is typical for each group (i.e., grade III, grade IVA, grade IVB etc.) of the patients, and surgery. In cases of slow progression of paraplegia, paraparesis, which preceded a plegia, was not considered of clinical sign typical for the grade.

Two types of anesthesia in dogs were used according to their general condition. Patients without a risk of anesthesia according to ASA classification (Paddleford and Erhardt 1992) were premedicated with $30-50 \mathrm{mg} / \mathrm{kg}$ of medetomidine (Domitor ${ }^{\circledR}$, Pfizer GmbH, Germany) given IM. General anesthesia was induced with propofol (Diprivan ${ }^{\circledR}$, Zeneca Limited, Great Britain) 2-4 mg/kg IV to effect. Endotracheal intubation was performed and a surgical plane of anesthesia was maintained by administration of a mixture of oxygen and halothane $\left(\operatorname{Narcotan}^{\circledR}\right.$, Léčiva, Czech Republic) (1.0-2.5\%). Potential risk patients according to ASA classification were premedicated with combination of droperidol $0.5-0.8 \mathrm{mg} / \mathrm{kg}$ and fentanyl in dose $10-16 \mu \mathrm{g} / \mathrm{kg}$ (Thalamonal ${ }^{\circledR}$, Janssen Pharmaceutica, Belgium) given IV, and induced with propofol $2-4 \mathrm{mg} / \mathrm{kg}$ IV to effect. Isoflurane (Forane ${ }^{\circledR}$, Abbott Laboratories Ltd., Great Britain) (1.0-2.5\%) was used instead of halothane for inhalation anesthesia. Antibiotics (cefazolin $22 \mathrm{mg} / \mathrm{kg}$ IV; Kefzol ${ }^{\circledR}$, Eli Lilly Italia S.p.A., Italy), steroids (methylprednisolone sodium succinate 30 
$\mathrm{mg} / \mathrm{kg}$ slow IV infusion; Solu-Medrol ${ }^{\circledR}$, Upjohn s.a., Puurs, Belgium) and ranitidine (1-2 mg/kg; Ulcosan ${ }^{\circledR}$, Galena, Czech Republic) were given perioperatively.

Survey radiographic examination and myelography, using transmedullary lumbar puncture between the L5 and L6 vertebrae, were performed prior to surgery. Iopamidol $\left(200 \mathrm{mg} \mathrm{I} / \mathrm{ml}\right.$; Iopamiro ${ }^{\circledR} 200$, Bracco s.p.a., Italy) at a dose of $0.3-0.45 \mathrm{ml} / \mathrm{kg}$ was used. Lateral myelographic views were examined for evidence of an extradural mass and extent of spinal cord edema and the ventrodorsal view was examined for evidence of lateralisation of herniated disc material.

Dogs were treated by hemilaminectomy with removal of extruded disc material from the vertebral canal. Prophylactic fenestrations of other discs in the at risk region of thoracolumbar spine (from T11-T12 to L3-L4) were not performed. A dorsolateral (Gage 1975) approach was employed. The facet joints were not preserved. Rightsided versus left-sided hemilaminectomy was chosen based upon clinical and/or myelographic signs of lateralisation of the lesion. A durotomy was performed in selected cases to visualise the spinal cord or to relieve intradural pressure. Hypothermic or normothermic saline solution was used to lavage the spinal cord throughout the procedure and a free autogenous fat graft was placed over the spinal cord after decompression and prior to routine closure of wound. Postoperatively, the urinary bladder was manually expressed 3 times a day until voluntary control of urination was evident. Physiotherapy consisted of daily passive range of motion exercises for all of the joints of the pelvic limbs. Animals were hospitalised from 4 to 12 days in our clinic. Searching for necessary data we used clinical records on hospitalised patients, and outpatients, respectively. Long-term follow up was obtained by examination of the dog at our hospital when feasible, and by a telephone conversation with the owner when not. Owners were asked to estimate the time taken until their dogs regained the ability to walk without assistance and to describe the most complete extent of recovery that was evident in the dog and the time at which this was noted following surgery. Residual weakness and/or incoordination, and recurrence of back pain, paresis or paralysis were also recorded. Patients were observed at least 9 months after surgery ( $9-51$ months follow-up) and results of the therapy were classified as excellent (complete recovery of motor and urinary function), very good (minimal motor deficit when walking on a slippery surface, and complete recovery of urinary bladder function), fair (obvious remaining dysfunction, either motor or urinary, but animal retained independent function and usefulness) and poor (not enough improvement to be returned to owner as an independent animal). Recurrence of neurological deficits in this group of clinical patients treated for thoracolumbar disc extrusion with a decompressive procedure alone (hemilaminectomy) was assessed. Mean time between two consecutive clinical episodes involving different disc herniation sites was analysed.

Means and standard deviations were calculated for all variables. The breed predisposition and outcome of surgery depending on the pre-operative neurological grade of spinal injury and duration of clinical signs were tested using $c^{2}$-test. Statistical analyses were done using Stat plus 1.10 (Matoušková et al. 1992).

\section{Results}

The incidence of thoracolumbar disc herniation in a population of 15,023 dogs seen at our hospital during the four year period was assessed (1.97\% of total surgical patient number). Twenty-four different breeds, including mixed-breed, were represented in the 300 clinical cases of thoracolumbar disc disease. The most commonly affected breeds in our study were: Dachshund $(71.00 \%)$, mixed-breed $(8.67 \%)$, Pekingese $(4.67 \%)$, Cocker Spaniel $(2.67 \%)$, Miniature Schnauzer (1,67\%), Poodle (1.67\%), French Bulldog (1.67\%), Lhasa-apso $(1.33 \%)$, Basset hound (1.00\%), American Cocker $(0.67 \%)$ and Shih-tzu $(0.67 \%)$. Predisposition to IVDD was confirmed in all these breeds using $c^{2}$-test $(p<0.01)$. The age of the dogs varied from 2 to 13 years with an average of $6.82 \pm 1.58$ years. One hundred and seventy-two dogs $(57.33 \%)$ were males and one hundred and twenty-eight $(42.67 \%)$ were females. Twenty-nine dogs $(10.32 \%)$ had earlier episodes of pain or hindlimb paresis.

The total number of herniations found in our 300 patients was 330. The most common lesion site was the T12-T13 interspace $(28.48 \%$ of extruded discs), followed by T13-L1 (23.64\%), T11-T12 (12.73\%) and L1-L2 (11.82\%). The disc extrusions were lateralized in the spinal canal (obviously on the left or right side of spinal cord) in $64.85 \%$ of the lesions (214 of 330 extruded discs). Herniated disc material was found ventral and lateral to the spinal cord in 52 lesions (15.75\%), just ventral in 59 lesions (17.88\%), and just dorsal in 5 lesions $(1.52 \%)$. The incidence of multiple disc extrusions was $9.33 \%$ (28 of 300 cases). In 26 dogs two distinct disc herniations were evident, and in two dogs three distinct disc herniations were found. Single disc extrusions were found in the remaining 272 dogs ( $90.66 \%$ of the cases). 
All dogs were treated by hemilaminectomy without prophylactic fenestration of other disc spaces. The results of treatment in ten dogs with grade II involvement were excellent in $80 \%$ of these dogs, very good in $10.00 \%$, and fair in $10.00 \%$. The results of treatment in 68 dogs with grade III involvement were excellent in $80.88 \%$ of these patients, very good in $8.82 \%$, and fair in $10.29 \%$ (see Fig. 1). The results of treatment in 111 dogs with grade IV A

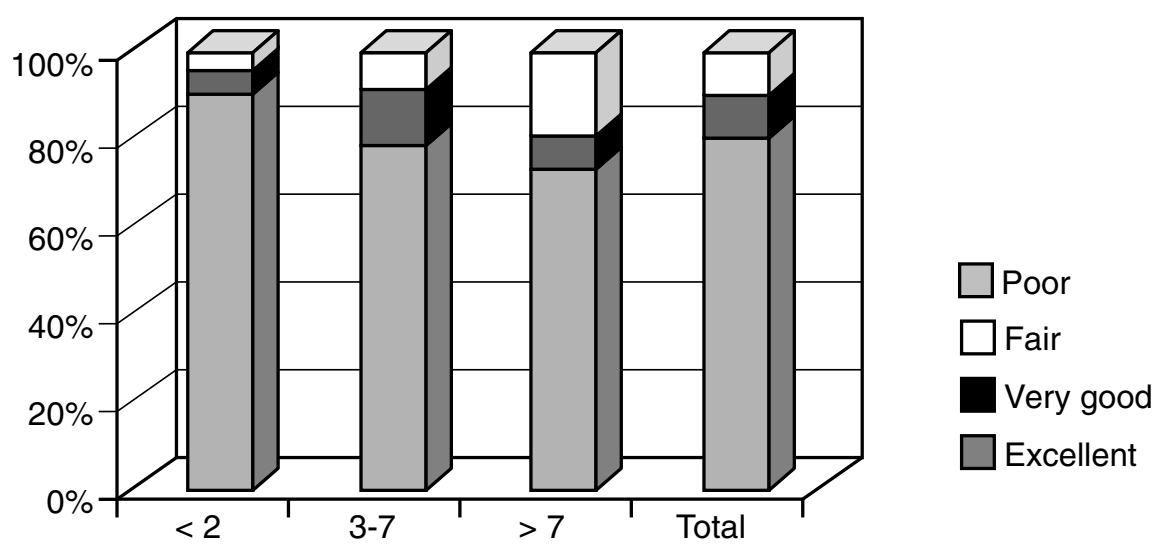

Duration of paraparesis before surgery (days)

Fig. 1. Results of surgical therapy in dogs of group III

involvement in which decompression was performed within 48 hours of the onset of clinical signs were excellent in $71.17 \%$ of these patients, very good in $12.61 \%$, fair in $14.42 \%$, and poor in $1.80 \%$. The results of treatment in 56 dogs with grade IV A involvement in which decompression was performed later than 48 hours after onset of paraplegia were excellent in $46.43 \%$ of these patients, very good in $25.00 \%$, fair in $17.87 \%$, and poor in $10.70 \%$ (see Fig. 2). Hemilaminectomy was performed in thirty-one dogs with severe

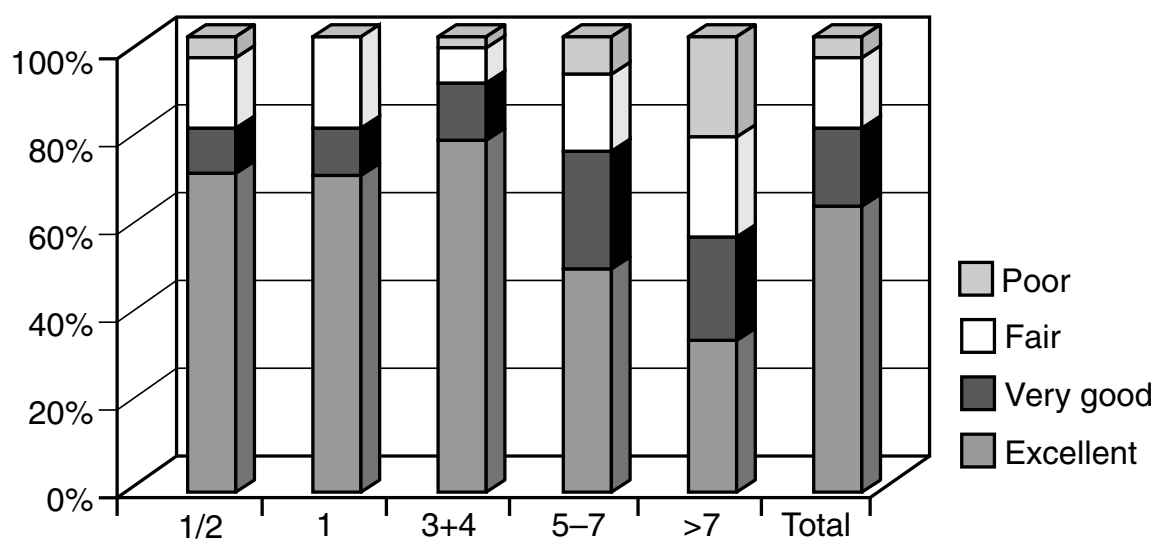

Duration of paraparesis before surgery (days)

Fig. 2. Results of surgical therapy in dogs of group IV A 


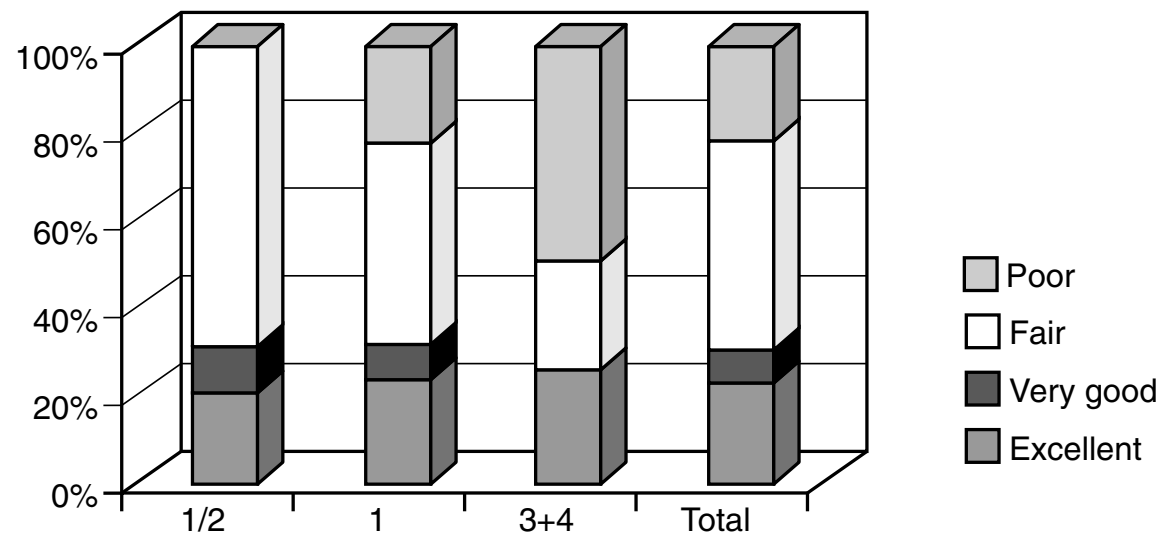

Duration of paraparesis before surgery (days)

Fig. 3. Results of surgical therapy in dogs of group IV B

neurological dysfunction (grade IV B) within 48 hours after onset of paraplegia. Outcome of the surgery was excellent in $22.58 \%$ of these patients, very good in $6.45 \%$, fair in $48.39 \%$, and poor in $22.58 \%$ (see Fig. 3). A durotomy was performed in 3 dogs with this severe neurological dysfunction, because of diffuse intramedullary swelling and/or intradural haemorrhage. The results of treatment in 5 dogs with grade IV C involvement were excellent in $40 \%$ of these patients, and fair in $60 \%$. Evaluating excellent and very good outcome of surgery (return to normal quality of life) compared to fair and poor result of therapy (dog with a handicap or depreciated quality of life) significant difference between dogs of grade IV A (deep pain intact; operated on within 48 hours after onset of clinical signs) and patients of grade IV B (no deep sensation up to 48 hours) paraplegia was found by $\mathrm{c}^{2}$-test $(\mathrm{p}<0.01)$.

Recurrence rate in the group of 281 dogs, observed from 9 to 51 months after surgery, was $14.59 \%$ (41 cases). Fourteen dogs had a recurrence of paraparesis (grade II and III) and twenty-seven dogs had paraplegia 1 to 30 months (median 9 months; mean $10.27 \pm 7.25$ months) after surgery. In all 41 cases, cause of the recurrence was extrusion of other disc.

\section{Discussion}

Dogs in our study represent typical sample of clinical patients, in which dachshunds predominate $(71 \%)$. In twenty from 24 breeds of dogs represented in our clinical sample of patients predispositon to IVDD was confirmed $\left(\mathrm{c}^{2}\right.$-test; $\mathrm{p}<0.01$ ). The age of the dogs (mean $6.82 \pm 1.58$ years) was similar to that in previous reports, as well (Gage 1975; Hoerlein 1978; Toombs and Bauer 1993).The kind of anesthesia in these patients was selected on the basis of compilation of published data (Paddleford and Erhardt 1992; Thurmon et al. 1996; Wooten and Lowrie 1993) and our own experiences obtained during surgical management of IVDD cases. Transmedullar technique of myelography (B arber et al. 1987), puncturing lumbar subarachnoidal space between L5-L6 vertebrae, were chosen. Recommended (Widmer et al. 1992) nonionic contrast medium at the $200-240 \mathrm{mg} \mathrm{I} / \mathrm{ml}$ range for canine myelography (Iopamiro ${ }^{\circledR} 200$ ) was used.

Twenty-nine dogs (10.32\%) had had earlier episodes of pain or hindlimb paresis. A total of $63.94 \%$ of disc protrusions in this study were between T12 and L2 vertebrae with T12T13 space being the most commonly affected $(28.48 \%)$. Other reports indicate a similar incidence (Brown et al. 1977; Levine and Caywood 1984). In all, 26 dogs from 281 patients extruded two discs and in 2 dogs prolapsed three discs simultaneously. This 
supports the view that recurrent disc problems are due to extrusion from other disc. B row et al. (1977) reported only one case of multiple disc extrusion in 32 dogs with recurrent pain and paresis.

The recovery rates with conservative therapy in dogs unable to walk have previously been cited as $45.7 \%$ (Funkquist 1962b). The results of decompressive surgery in dogs with similar degrees of spinal injury have been reported as $53.5 \%$ to $88.5 \%$ (Funkquist 1962c; B rown et al. 1977). In our study all dogs with grades II and III paresis, and $98.2 \%$ of dogs with grade IV A paraplegia, operated on within $48 \mathrm{~h}$, regained the ability to walk after surgery (excellent + very good + fair result of surgery). Concerning patients of IV A grade operated on later than $48 \mathrm{~h}$ after onset of paraplegia, $89,3 \%$ of them recovered to ability to walk (excellent + very good + fair outcome). Outcome of the surgery was not so good in dogs with loss of pain sensation no longer than $48 \mathrm{~h}$ (grade IV B). Only $77.42 \%$ regained this function. More obvious differences in results of this surgical method of therapy related to the pre-operative neurological grade of spinal injury and duration of clinical signs show Figs 1, 2, and 3, respectively. Significant difference $\left(c^{2}\right.$-test; $\left.p<0.01\right)$ in results of surgical therapy was found between dogs with grade IV A (no longer than $48 \mathrm{~h}$ ), and dogs of grade IV B paraplegia, respectively.

We did not perform routine prophylactic fenestrations of the high risk disc spaces of the thoracolumbar region because of the reported low incidence of subsequent disc herniations another site (Muir et al. 1995; Nečas 1995b; Prata 1981), the variable efficacy of fenestration related to the amount of nuclear material actually removed (Shores et al. 1985), and extended time of surgery, respectively. We used autogenous fat grafts, which have been advocated to prevent scar formation and invasion of the vertebral canal (Kiviluoto 1976).

We tightened the criteria used to classify the results of therapy. Instead of the classification of Hoerlein (1971) we used modified classification scheme (excellent, very good, fair and poor) enabled a more precise description of neurological deficits.

The probability of disc prolapse at another site after a dog had undergone decompressive surgery for the first disc herniation is a question that owners commonly ask due to the high cost of surgery. Therefore, we decided to assess the recurrence rate of disc disease caused by repetitive disc herniation, to be able to specify this part of the prognosis.

There are controversies about the treatment of thoracolumbar disc disease with regard to the necessity for decompressive surgery, the type of decompressive surgery, the necessity to retrieve extruded disc material, and the therapeutic value of disc fenestration. Fenestration of the thoracolumbar discs without decompressive surgery has been reported to be successful in the treatment of paralysed dogs (Denny 1978; Davies and Sharp 1983). Most authors advocate spinal cord decompression in dogs which are unable to walk and the status of various intervertebral surgeries has been evaluated (Hoerlein 1978). Dorsal laminectomy (Funkquist 1962c; Henry 1975; Horne et al. 1977; Trotter 1990) and hemilaminectomy with various modifications, including "minihemilaminectomy", have been described (Bitetto and Thacher 1987; Jeffery 1988; Nečas 1995a; Swaim 1987; Trotter 1989b; Wheeler and Sharp 1994). Early intervention and surgical decompression of the spinal cord are advocated in dogs with acute paraplegia due to intervertebral disc prolapse. This is situation similar to emergency spinal cases in people with thoracolumbar fractures (Chaloupka 1999; Vlach and Chaloupka 1997).

Hemilaminectomy is the most commonly used surgical procedure for spinal cord decompression and removal of herniated discs from vertebral canal (Cook 1992). The value of prophylactic fenestration of other disc spaces during the decompressive surgery is distinctively interpreted. It has been claimed that fenestration alone is successful for the treatment of thoracolumbar disc protrusions (Denny 1978; Davies and Sharp 1983). It 
has been shown to be advantageous in preventing the recurrence of disc protrusion in some studies (Davies and Sharp 1983) and to reduce, but not eliminate it, in others (Funkquist 1978; Levine and Caywood 1984). Recurrences after fenestration may result from the inadequate removal of the nucleus pulposus or from the protrusion of a previously unfenestrated disc. Prata (1981) mentions that recurrences involving other discs are not frequent enough to warrant prophylactic fenestrations. He shows rescurrence rate after laminectomy without concomitant disc disease in $2.7 \%$ of patients. In contrast to this implication is the opinion of Levine and Caywood (1984), who demonstrated significant reduction of recurrent symptoms of pain and paresis in patients receiving prophylactic fenestration. However, length of surgery must be somewhat extended when fenestrations accompany the decompression. Hoerlein (1987) and Trotter (1990) stated that prophylactic fenestrations do not require much time and are worthwhile. Complications of prophylactic fenestrations are rare and transient. They include pneumothorax (during thoracic disc fenestration), scoliosis, ventral abdominal muscle paralysis (due to spinal nerve damage), and femoral nerve deficit, respectively (Bartels et al. 1983). Fenestration of a partially ruptured disc might prevent further extrusion of material, but it can also cause further extrusion of an unstable disc and deterioration of neurological signs (Toombs and Bauer 1993). Information is available concerning the recurrence of neurological deficits in dogs treated for thoracolumbar disc disease with conservative therapy (40\%), with a decompressive procedure alone $(26.5 \%)$, with decompression and fenestrations (16.6\%), and with fenestrations alone (14.8\% of cases), respectively (Levine and Caywood 1984). Although the lowest recurrence rates were in dogs that received disc fenestrations, protection afforded by this technique was not absolute. Relapse of clinical signs may have different cause, i.e. other disc prolapse, or laminectomy membrane formation (Trotter 1989a; Trotter et al. 1988). To our knowledge, there are few reports in the literature on the recurrence rate of disc disease only due to herniation of other disc in thoracolumbar region of spine after decompressive surgery without prophylactic fenestration. In only $5 \%$ of dogs was a second laminectomy performed, one to two years after the first surgery, because of extrusion of a different intervertebral disc which had not been fenestrated at the time of the first decompressive operation (Muir et al. 1995). Our previous retrospective study of results of surgical treatment of the thoracolumbar disc disease in 90 patients, including prophylactic fenestration alone in twelve dogs with grade II paraparesis, and hemilaminectomy without fenestration of other discs in seventy-eight dogs with grades III, IV A and IV B, respectively, showed only $1.5 \%$ recurrence rate (Nečas 1995b). The findings are based on relatively short follow-up period (6-19 months after surgery). In our present study of 281 patients the follow-up period ranged from 9 to 51 months and only dogs treated by hemilaminectomy without other disc fenestrations were included. The recurrence rate $14.59 \%$ of patients in our study is noticeably higher compared to previous studies. Therefore, the routine prophylactic fenestration of discs in spaces T11-T12 through L3-L4 when performing decompressive surgery for IVDD might decrease this relatively high percentage of clinically significant recurrence of IVDD. The benefits of prophylactic disc fenestrations should outweigh any problems that might conceivably be induced by the procedure itself or the increase in anesthetic time. Effectiveness of fenestration depends on the amount of nucleus pulposus removed (Shores et al. 1985). Exact recurrence of disc disease after hemilaminectomy with prophylactic disc fenestrations due to possible protrusion of remaining disc material is not known. Further investigations in this area are desirable.

\section{Klinické aspekty chirurgické léčby onemocnění torakolumbálních} meziobratlových plotének u psů. Retrospektivní studie 300 př́ípadů.

V práci jsou uvedeny klinické aspekty dekompresní chirurgické léčby u 300 psů $\mathrm{s}$ onemocněním torakolumbálních meziobratlových plotének na Klinice chirurgie 
a ortopedie Veterinární a farmaceutické university v Brně v průběhu čtyř let (duben 1994 až březen 1998). Byla zjištěna plemenná predispozice, stáří a pohlaví pacientů v souboru, frekvence výskytu extruze disků $\mathrm{v}$ jednotlivých meziobratlových prostorech torakolumbálního úseku páteře a poloha extrudovaných mas disku vzhledem $\mathrm{k}$ míše. Sledován byl rovněž počet jedinců s výhřezem více disků současně. Psi byli podle závažnosti klinických př́iznaků rozděleni do pěti skupin (I, II, III, IV A, IV B a IV C). Úspěšnost operace $\mathrm{v}$ těchto skupinách byla porovnána $\mathrm{v}$ závislosti na stupni postižení před operací a na době trvání klinických př́iznaků. Neurologický stav pacientů byl sledován nejméně 9 měsíců po operaci. Všichni psi byli léčeni hemilaminektomií bez fenestrace okolních meziobratlových plotének v oblasti přechodu hrudní a bederní páteře. U psů se stupněm postižení II byl výsledek léčby výborný u $80 \%$, velmi dobrý u $10 \%$ a uspokojivý u $10 \%$ takto postižených jedinců. Z 68 psů s paraparézou stupně III bylo po operaci $80,88 \%$ jedinců výborných, 8,82\% velmi dobrých a 10,29\% se zotavilo uspokojivě. Výsledky léčby u 111 psů s postižením stupně IV A, byla-li operace provedena do 48 hodin od vzniku klinických příznaků, byly výborné u 71,17\%, velmi dobré u 12,61\%, uspokojivé u $14,42 \%$ a špatné u 1,80\% pacientů. Z 56 psů se stupněm postižení IV A, ošetřených za více než 48 hodin od vzniku paraplegie, bylo po operaci výborných pouze $46,43 \%$ jedinců, velmi dobrých $25 \%$, uspokojivý byl výsledek operace u $17,87 \%$ a špatný u $10,70 \%$ psů. U 31 psů s těžkou neurologickou dysfunkcí stupně IV B trvající ne déle než 48 hodin byl výsledek operace výborný ve $22,58 \%$ př́ipadů, velmi dobrý v $6,45 \%$, uspokojivý ve 48,39\% a špatný ve $22.58 \%$ případů. Výsledky léčby u 5 psů s paraplegií stupně IV C byly ve $40 \%$ případů výborné a v $60 \%$ př́ípadů uspokojivé.

$\mathrm{V}$ průběhu perioperačního období uhynulo 19 pacientů, kteří tak nemohli být použiti pro dlouhodobé hodnocení úspěšnosti operace. Ve zbývající skupině 281 psů byl stanoven počet recidiv onemocnění torakolumbálních meziobratlových plotének. Pacienti byli sledováni 9 až 51 měsíců po chirurgickém zákroku a zjištěné procento recidiv činilo 14,59\% (41 psů). U čtrnácti psů se recidiva projevila paraparézou (stupeň postižení II a III) a u dvaceti sedmi psů paraplegií (stupeň IV) v rozmezí 1 až 30 měsíců ( $10,27 \pm 7,25$ měsíců) po operaci. Ve všech 41 případech byl příčinou recidivy výhřez jiné meziobratlové ploténky.

\section{References}

BARBER, D.L., OLIVER, J.E., MAYHEW, I.G. 1987: Neuroradiography. In: OLIVER, J.E., HOERLEIN, B.F., MAYHEW, I.G.:Veterinary neurology. W.B. Saunders, Philadelphia, pp. 65-110

BARTELS, K.E., CREED, J.E., YTURRASPE, D.J. 1983: Complications associated wiht the dorsolateral muscle separating approach for thoracolumbar disk fenestration in the dog. J. Am. Vet. Med. Assoc. 183: 108-110

BITETTO, W.V., THACHER, C. 1987: A Modified Lateral Decompressive Technique for Treatment of Canine Intervertebral Disk Disease. J. Am. Anim. Hosp. Assoc. 23: 409-413

BRAUND, K.G. 1981: Canine intervertebral disc disease. In: BOJRAB, M.J.: Pathophysiology of small animal surgery. Lea and Febiger. Philadelphia, pp. 739-746

BRAUND, K.G., GHOSH, P., TAYLOR, T.K.F., LARSEN, L.H. 1975: Morphological studies of the canine intervertebral disk. The assignment of the beagle to the achondroplastic classification. Res. Vet. Sci. 19: 167172

BRAY, J.P., BURBIDGE, H.M. 1998: The Canine Intervertebral Disk. Part Two: Degenerative ChangesNonchondrodystrophoid versus Chondrodystrophoid Disks. J. Am. Anim. Hosp. Assoc. 34: 135-144

BROWN, N.O., HELPHREY, M.L., PRATA, R.G. 1977: Thoracolumbar disk disease in the dog: A retrospective analysis of 187 cases. J. Am. Anim. Hosp. Assoc. 13: 665-672

COOK Jr., J.R. 1992: Decompressive Procedures. Indications and Techniques. Vet. Clin. North Am. Small Anim. Pract. 22: 917-921

CHALOUPKA, R. 1999: Complete rational burst fracture of the third lumbar vertebra managed by posterior surgery: A case report. Spine 24: 302-305

DAVIES, J.V., SHARP, N.J.H. 1983: A comparison of conservative treatment and fenestration for thoracolumbar intervertebral disc disease in the dog. J. Small Anim. Pract. 24: 721-729

DENNY, H.R. 1978: The lateral fenestration of canine thoracolumbar disc protrusions: a review of 30 cases. J. Small Anim. Pract. 19: 259-266 
DUNCAN, J.R., OLIVER, J.E., MAYHEW, I.G. 1987: Laboratory examinations. In: OLIVER, J.E., HOERLEIN, B.F., MAYHEW, I.G.: Veterinary neurology. W. B. Saunders, Philadelphia, pp. 57-64

FUNKQUIST, B. 1978: Investigations of the therapeutic and prophylactic effects of disc evacuation in cases of thoraco-lumbar herniated discs in dogs. Acta Vet. Scand. 19: 441-457

FUNKQUIST, B. 1962a: Thoraco-lumbar disk protrusion with severe cord compression in the dog. I. Clinical and patho-anatomic observations with special reference to the rate of development of the symptoms of motor loss. Acta Vet. Scand. 3: 256-274

FUNKQUIST, B. 1962b: Thoraco-lumbar disk protrusion with severe cord compression in the dog. II. Clinical observations with special reference to the prognosis in conservative treatment. Acta Vet. Scand. 3: 317-343

FUNKQUIST, B. 1962c: Thoraco-lumbar disk protrusion with severe cord compression in the dog. III. Treatment by decompressive laminectomy. Acta Vet. Scand. 3: 344-366

GAGE, E.D. 1975: Modifications in Dorsolateral Hemilaminectomy and Disc Fenestration in the Dog. J. Am. Anim. Hosp. Assoc. 11: 407-411

GHOSH, P., TAYLOR, T.K.F., BRAUND, K.G. 1977a: Variation of the glycosaminoglycans of the intervertebral disk with aging. II: the non-chondrodystrophic breed. Gerontology. 23: 99-109

GHOSH, P., TAYLOR, T.K.F., BRAUND, K.G. 1977b: Variation of the glycosaminoglycans of the intervertebral disk with aging. I: the chondrodystrophoid breed. Gerontology 23: 87-98

GRIFFITHS, I.R. 1972: Some aspects of the pathogenesis and diagnosis of lumbar disc protrusion in the dog. J. Small Anim. Pract. 13: 439-447

HENRY Jr., W.B. 1975: Dorsal Decompressive Laminectomy in the Treatment of Thoraco-Lumbar Disc Disease. J. Am. Anim. Hosp. Assoc. 11: 627-635

HOERLEIN, B.F. 1987: Intervertebral disc disease. In: OLIVER, J.E., HOERLEIN, B.F., MAYHEW, I.G.:Veterinary neurology. W.B. Saunders, Philadelphia, pp. 321-340

HOERLEIN, B.F. 1971: Intervertebral disks. In: HOERLEIN, B.F.: Canine neurology. W.B. Saunders, Philadelphia, pp. 307-391

HOERLEIN, B.F. 1953: Intervertebral Disc Protrusions in the Dog. I. Incidence and Pathological Lesions. Am. J. Vet. Res. 14: 260-269

HOERLEIN, B.F. 1978: The Status of the Various Intervertebral Disc Surgeries for the Dog in 1978. J. Am. Anim. Hosp. Assoc. 14: 563-570

HORNE, T.R., POWERS, R.D., SWAIM, S.F. 1977: Dorsal Laminectomy Technigues in the Dog. J. Am. Vet. Med. Assoc. 171: 742-749

JEFFERY, N.D. 1988: Treatment of acute and chronic thoracolumbar disc disease by „mini hemilaminectomy“. J. Small Anim. Pract. 29: 611-615

KIVILUOTO, O. 1976: Use of free fat transplants to prevent epidural scar formation. An experimental study. Acta Orthop. Scand. 164: 8-70

LAMERS, K.J.B., WEVERS, R.A. 1995: Cerebrospinal Fluid Diagnostics: Biochemical and Clinical Aspects. Klin. Biochem. Metab. 3: 63-75

LEVINE, S.H., CAYWOOD, D.D. 1984: Recurrence of neurological deficits in dogs treated for thoracolumbar disc disease. J. Am. Anim. Hosp. Assoc. 20: 889-891

MAYHEW, I.G., BEAL, C.R. 1980: Techniques of Analysis of Cerebrospinal Fluid. Vet. Clin. North Am. Small Anim. Pract. 10: $155-176$

MATOUŠKOVÁ, O., CHALUPA, J., CÍGLER, M, HRUŠKA, K. 1992: STAT plus - uživatelská příručka, VÚVeL Brno, $168 \mathrm{p}$.

MUIR, P., JOHNSON, K.A., MANLEY, P.A., DUELAND, R.T. 1995: Comparison of hemilaminectomy and dorsal laminectomy for thoracolumbar intervertebral disc extrusion in dachshunds. J. Small Anim. Pract. 36: 360-367

NEČAS, A. 1995a: Neurosurgical treatment of intervertebral disc disease in the dog. Vet. Med.-Czech. 40: 299-304

NEČAS, A. 1995b: Results of surgical treatment of the thoracolumbar disc disease in the dog. Vet. Med.-Czech. 40: $213-216$

PADDLEFORD, R.R., ERHARDT, W. 1992: Anästhesie bei Kleintieren. Schattauer, Stuttgart-New York, 413 p.

PRATA, R.G. 1981: Neurosurgical treatment of thoracolumbar discs: The rationale and value of laminectomy with concomitant disc removal. J. Am. Anim. Hosp. Assoc. 17: 17-26

PRIESTER, W.A. 1976: Canine intervertebral disc disease - occurrence by age, breed, and sex among 8,117 cases. Theriogenology 6: 293-296

SHORES, A., CECHNER, P.E., CANTWELL, H.D., WHEATON, L.G., CARLTON, W.W. 1985: Structural Changes in Thoracolumbar Disks Following Lateral Fenestration. A Study of the Radiographic, Histologic, and Histochemical Changes in the Chondrodystrophoid Dog. Vet. Surg. 14: 117-123

SWAIM, S.F. 1987: Vertebral and spinal cord surgery. In: OLIVER, J.E., HOERLEIN, B.F., MAYHEW, I.G.:Veterinary neurology. W.B. Saunders, Philadelphia, pp. 416-442

THURMON, J.C., TRANQUILLI, W.J., BENSON, G.J. 1996: Lumb Jones Veterinary Anesthesia. $3^{\text {rd }}$ ed. Williams Wilkins, Baltimore, 928 p.

TOOMBS, J.P., BAUER, M.S. 1993: Intervertebral Disc Disease. In: SLATTER, D: Textbook of Small Animal Surgery. $2^{\text {nd }}$ ed. W. B. Saunders, Philadelphia, pp. 1070-1087 
TROTTER, E.J. 1990: Dorsal laminectomy for treatment of thoracolumbar disk disease. In BOJRAB, M.J.: Current techniques in small animal surgery. Lea and Febiger, Philadelphia, pp. 608-621

TROTTER, E.J. 1989a: Laminectomy membrane formation Proceedings of ECVS annual forum. October 23 , Chicago, USA, pp. 231-233

TROTTER, E.J. 1989b: Thoracolumbar disc disease - treatment by modified dorsal laminectomy. Proceedings of ECVS annual forum. October 23, Chicago, USA, pp. 227-230

TROTTER, E.J., CRISSMAN, J., RABSON, D., BABISH, J. 1988: Influence of nonbiologic implants on laminectomy membrane formation in dogs. Am. J. Vet. Res. 49: 634-642

VLACH, O., CHALOUPKA, R. 1997: Zásady ošetření úrazů páteře. Acta Chir. Orthop. Traum. Čech. 64: 227-231 WHEELER, S.J., SHARP, N.H.J. 1994: Small animal spinal disorders. Diagnosis and surgery. Mosby, London, $222 \mathrm{p}$.

WIDMER, W.R., BLEVINS, W.E., JAKOVLJEVIC, S., TECLAW, R.F., HAN, C.M., HURD, C.D. 1992: Iohexol and iopamidol myelography in the dog: a clinical trial comparing adverse effects and myelographic quality. Veterinary Radiology Ultrasound. 33: 327-333

WOOTEN, T.L., LOWRIE, C.T. 1993: Comparison of cerebrospinal fluid pressure in propofol- and thiopentalanesthetized eucapnic dogs. Vet. Surg. 22: 148-150 